\title{
ВЗАЄМОЗАЛЕЖНІСТЬ ПРО- Й АНТИОКСИДАНТНОГО СТАТУСУ I КАЛІКРЕЇН-КІНІНОВОЇ СИСТЕМИ У ТВАРИН РІЗНОГО ВІКУ ЗА УМОВ РАННЬОЇ ТА ПІЗНЬОЇ ПОЛІТРАВМИ
}

Вступ. Останні десятиріччя характеризуються значним зростанням травматизму, особливо осіб молодого віку, який має різноманітні причини. Однією з патогенетичних ланок травматичної хвороби $\epsilon$ порушення прооксидантно-антиоксидантної та калікреїн-кінінової систем. Дані про зміни показників пероксидного окиснення ліпідів - антиоксидантного захисту - калікреїн-кінінової системи в осіб різного віку і в різні періоди травматичної хвороби розрізнені та суперечливі.

Мета дослідження-встановити взаємозалежність між показниками про-й антиоксидантної систем та показниками загального і специфічного протеолізу в щурів різного віку при ранніх та пізніх проявах політравми.

Методи дослідження. Політравму моделювали під тіопентал-натрієвим знеболюванням (60 мг/к2 маси тіла тварини). В асептичних умовах у тварин зі стегнової вени викликали кровотечу (близько 20 \% об'єму циркулюючої крові), 1 мл якої вводили в паранефральну клітковину для відтворення ендогенної інтоксикації. Далі з оперативного доступу щипцями Люера ламали ліву стегнову кістку, рану на стегні зашивали. Дослідження проводили на 1, 3, 24 годину та 14 добу після моделювання політравми. Активність супероксиддисмутази в сироватці крові визначали за методикою Чеварі, активність каталази в гомогенаті печінки та плазмі крові - за методикою М. А. Королюка і співавт., вміст церулоплазміну в сироватці крові - за методикою В. Г. Колба, В. С. Камишнікова, вміст ТБК-активних продуктів - за методикою В. Б. Гаврилова, а показники калікреїн-кінінової системи - за методикою К. М. Веремєєнко. Взаємозв'язок двох ознак при наявності нормального розподілу оцінювали за результатами кореляційного аналізу за Пірсоном (r).

Результати й обговорення. Проаналізувавши взаємозв'язок між показниками про- й антиоксидантної систем та показниками загального і специорічного протеолізу в ранні терміни травматичної хвороби у тварин 3-місячного віку, ми встановили наявність оберненої статистично значимої кореляції між рівнем калікреїну й активністю супероксиддисмутази $(r=-0,69 ; p<0,05)$ на 1 годину після моделювання політравми. Про активацію неспецифрічного протеолізу свідчила наявність прямих статистично значимих кореляційних зв'язків між протеолітичною активністю і рівнем малонового діальдегіду $(r=0,65 ; p<0,05)$ на 1 годину та між протеолітичною активністю і рівнем гідропероксидів ліпідів на 3 годину травматичної хвороби $(r=0,67 ; p<0,05)$. Зменшення захисних механізмів системи антиоксидантного захисту підтверджувала значима обернена кореляція між протеолітичною активністю і рівнем каталази у крові тварин 3-місячного віку в ранні терміни політравми (r=-0,67; p<0,05). У статевозрілих 6-місячних щурів на 1 годину після моделювання політравми засріксовано обернені статистично значимі кореляційні зв'язки між рівнями калікреїну, каталази в крові й церулоплазміну в сироватці крові ( $r=0,89$ i $r=0,72$ відповідно; $p<0,05)$. На 3 годину експерименту встановлено наявність обернених кореляційних зв'язків між рівнем прекалікреїну й активністю каталази в печінці $(r=-0,80 ; p<0,05)$, що доводить зменшення захисних ресурсів системи антиоксидантного захисту на тлі активації калікреїн-кінінової системи.

Висновок. Виявлені кореляційні зв'язки підтверджують те, що зростання інтенсифрікації процесів пероксидного окиснення ліпідів, активація загального та специфрічного протеолізу калікреїн-кінінової системи та зменшення адаптаційних ресурсів системи антиоксидантного захисту призводять до поглиблення ліпідного дисбалансу у тварин різних вікових груп з політравмою і, навпаки, поглиблення порушень у ліпідному статусі спричиняє підвищення дисбалансу пероксидного окиснення ліпідів - антиоксидантного захисту - калікреїн-кінінової системи.

КЛЮЧОВІ СЛОВА: політравма; щури; вік; пероксидне окиснення ліпідів; антиоксиданти; калікреїнкінінова система.

ВСТУП. На сьогодні в Україні, як майже в усьому світі, відмічають значне підвищення рівня і тяжкості травматичних ушкоджень [1]. Важливими патогенетичними механізмами травматичної хвороби є зміни прооксидантно-антиокси๑) С. Р. Підручна, Г. М. Степанова, 2017. дантного балансу та порушення калікреїн-кінінової системи (ККС). Більшість авторів вважає, що тим інтимним механізмом, який відіграє ключову роль у дезорганізації ультраструктури мембран, $€$ активація реакцій вільнорадикального окиснення. Протидіє переокисненню ліпідів біомембран 
успішне функціонування системи антиоксидантного захисту (AO3) [2]. Дані літератури про зміни цієї системи за умов тяжкої травми розрізнені й суперечливі. Калікреїн-кінінова система $є$ регуляторною ланкою, яка направлена на здійснення адаптації організму до умов внутрішнього і зовнішнього середовища, які постійно змінюються. На даний час ККС належить до найбільш інтенсивно досліджуваних протеолітичних систем організму. Стан показників ККС відображає активність запальної реакції в організмі, стан мікроциркуляції, тяжкість перебігу захворювання. Калікреїн-кінінова система - одна із центральних систем, що регулюють гомеостаз і здійснюють адаптивно-захисні реакції [2, 3]. Однак є небагато публікацій, в яких би відображалася взаємозалежність про- й антиоксидантного статусу і калікреїн-кінінової системи в особин різного віку за умов ранньої та пізньої політравми.

Мета дослідження - встановити взаємозалежність між показниками про- й антиоксидантної систем та показниками загального і специфічного протеолізу в щурів різного віку при ранніх та пізніх проявах політравми.

МЕТОДИ ДОСЛІДЖЕННЯ. В експерименті використано 120 нелінійних білих щурів віком 3, 6 та 24 місяці. У дослідній групі в асептичних умовах під легким ефрірним наркозом моделювали тяжку травму [4]. Контрольну групу становили інтактні тварини, яких утримували в стандартних умовах віварію. На 1, 3, 24 годину та 14 добу після травмування за умов тіопентал-натрієвого знеболювання в щурів забирали кров для біохімічних досліджень, дотримуючись принципів Європейської конвенції про захист хребетних тварин, що використовуються для дослідних та інших наукових цілей (Страсбург, 1986). У сироватці крові визначали вміст прекалікреїну (ПКК) і калікреїну (КК) та протеолітичну активність (ПРА) [5]. Про активність процесів ліпопероксидації судили за вмістом ТБК-активних продуктів [6]. Активність супероксиддисмутази (СОД) у сироватці крові визначали за методикою Чеварі [7], активність каталази (КАТ) в гомогенаті печінки та плазмі крові-за методикою М. А. Королюка і співавт. [8], вміст церулоплазміну (ЦП) у сироватці крові - за методикою В. Г. Колба, В. С. Камишнікова [9].

Статистичну обробку матеріалу проводили параметричними методами. При перевірці статистичних гіпотез нульову гіпотезу відкидали при рівні статистичної значущості (р) менше 0,05. Наявність і вірогідність розходжень між вибірковими середніми величинами незалежних вибірок оцінювали за допомогою параметричного критерію Стьюдента.
Взаємозв'язок двох ознак при наявності нормального розподілу оцінювали за результатами кореляційного аналізу за Пірсоном (r). Вірогідність коефіцієнтів кореляції оцінювали, порівнюючи розраховані коефіцієнти з критичними (з огляду на властивості коефіцієнтів кореляції та ступені свободи).

РЕЗУЛЬТАТИ Й ОБГОВОРЕННЯ. Проаналізувавши взаємозв'язок між показниками про- й антиоксидантної систем та показниками загального і специфічного протеолізу в ранні терміни травматичної хвороби у тварин 3-місячного віку, ми встановили наявність оберненої статистично значимої кореляції між рівнями КК і ЦП у сироватці крові $(r=-0,64 ; p<0,05)$ на 3 годину та між рівнем КК і активністю СОД $(r=-0,69 ; p<0,05)$ на 1 годину після моделювання політравми (рис. 1). Це підтверджує активацію специсічного протеолізу на тлі інтенсиорікації процесів ліпопероксидації в ранні терміни травматичного ураження. Про активацію неспецифрічного протеолізу свідчила наявність прямих статистично значимих кореляційних зв'язків між ПРА і рівнем малонового діальдегіду (МДА) $(r=0,65 ; p<0,05)$ на 1 годину та між ПРА і рівнем гідропероксидів ліпідів (ГП) на 3 годину травматичної хвороби ( $r=0,67$; p<0,05). Зменшення захисних механізмів системи АОЗ підтверджувала значима обернена кореляція між ПРА і КАТ у крові тварин 3-місячного віку в ранні терміни політравми $(r=-0,67 ; p<0,05)$.

У пізні терміни політравматичного ураження також простежувалася активація специсрічної і неспецифічної ланок ККС на тлі послаблення потенціалів системи АОЗ, що було підтверджено встановленням прямих кореляційних зв'язків між ПРА й активністю КАТ у печінці $(r=0,73 ; p<0,05)$ та між КК і активністю КАТ у крові $(r=0,69 ; p<0,05)$ в 3-місячних тварин.

У статевозрілих 6-місячних щурів на 1 годину після моделювання політравми зафріксовано обернені статистично значимі кореляційні зв'язки між рівнями ПКК й окисномодисрікованих білків основного характеру $\left(\mathrm{OMБ}_{430}\right)$ у печінці $(r=0,82 ; p<0,05)$ (рис. 2) та між рівнями КК, КАТ у крові й ЦП у сироватці крові ( $r=0,89$ і $r=0,72$ відповідно; $p<0,05)$. На 3 годину експерименту встановлено наявність обернених кореляційних зв'язків між рівнем ПКК і активністю КАТ у печінці ( $r=-0,80 ; p<0,05)$, що доводить зменшення захисних ресурсів системи АОЗ на тлі активації $\mathrm{KKC}$.

На 24 годину після моделювання політравми у статевозрілих тварин було зафріксовано прямі статистично значимі кореляційні зв'язки між ПРА і рівнем окисномодифікованих білків кислого характеру $\left(\mathrm{OMБ}_{370}\right)$ у крові $(r=0,67 ; p<0,05)$ та між 

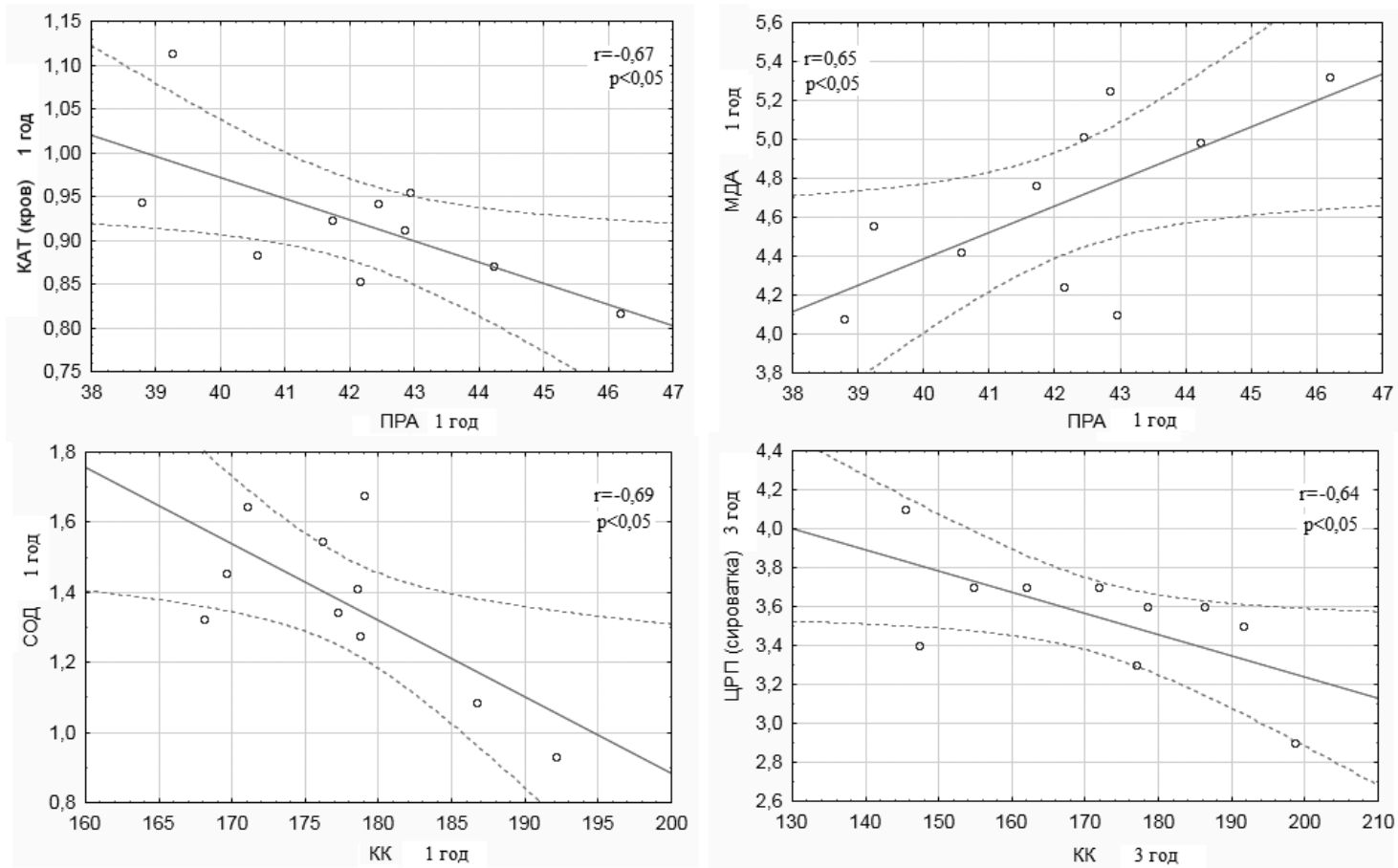

Рис. 1. Кореляційні зв'язки між показниками пероксидного окиснення ліпідів - антиоксидантного захисту - калікреїнкінінової системи в 3-місячних щурів у ранні терміни після моделювання політравми.
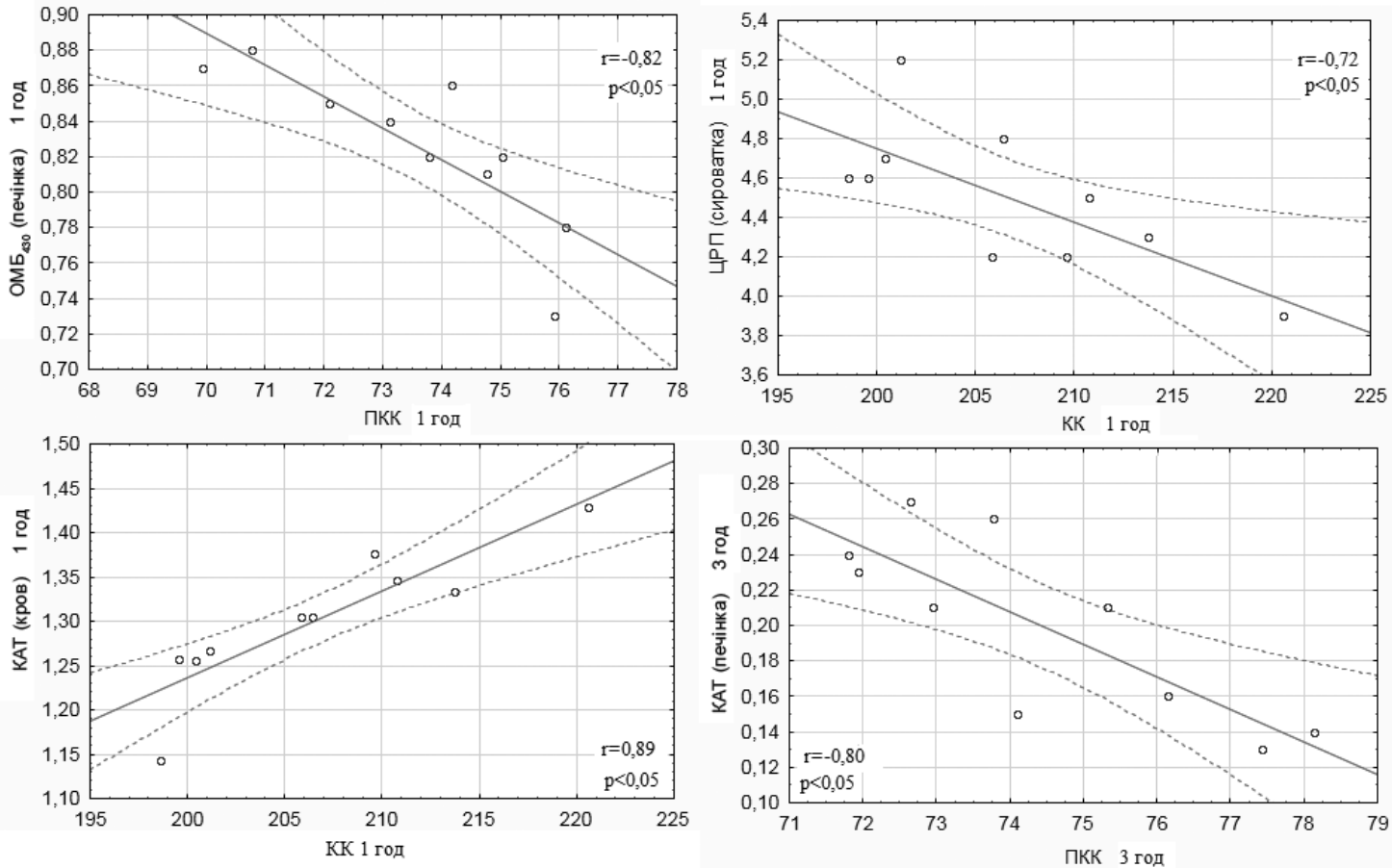

Рис. 2. Кореляційні зв'язки між показниками пероксидного окиснення ліпідів - антиоксидантного захисту - калікреїнкінінової системи у 6-місячних щурів у ранні терміни після моделювання політравми.

рівнями ПКК і ОМБ ( $r=0,71$ i $r=0,76$ відповідно; $p<0,05)$.

Наявність обернених статистично значимих кореляційних зв'язків між ПРА і рівнем ГП у крові $(r=-0,77 ; p<0,05)$ та між рівнями ПКК і ОМБ в печінці $(r=-0,71 ; p<0,05)$ у 6-місячних тварин у пізні терміни політравми (14 доба) засвідчує предикторність інтенсифікації пероксидного окиснення ліпідів в активації загального та спе- цифічного протеолізу. Послаблення АОЗ у статевозрілих щурів у пізні терміни ураження підтверджувалось прямою статистично значимою кореляцією між ПРА і рівнем ЦП у сироватці крові $(r=0,71 ; p<0,05)$.

У 24-місячних тварин не відмічали взаємозалежності між показниками про- й антиоксидантного статусу і показниками ККС на 1 і 3 годину після моделювання політравми. Лише на 
24 годину експерименту було встановлено прямі статистично значимі кореляційні зв'язки між ПРА й активністю КАТ у печінці ( $r=0,66$; $\mathrm{p}<0,05)$, тобто було виявлено пряму залежність між активністю неспецифрічного протеолізу та послабленням АОЗ у 24-місячних тварин у ранні терміни політравми. У пізні терміни після моделювання політравми (14 доба) статистично значимих кореляційних зв'язків між показниками загального і специсрічного протеолізу та показниками пероксидного окиснення ліпідів - антиоксидантного захисту - калікреїн-кінінової системи не відмічали.

ВИСНОВКИ. Виявлені кореляційні зв'язки підтверджують те, що зростання інтенсифрікації процесів пероксидного окиснення ліпідів, активація загального та специфічного протеолізу ККС та зменшення адаптаційних ресурсів системи АОЗ призводять до поглиблення ліпідного дисбалансу у тварин різних вікових груп з політравмою i, навпаки, поглиблення порушень у ліпід- ному статусі спричиняє підвищення дисбалансу пероксидного окиснення ліпідів - антиоксидантного захисту - калікреїн-кінінової системи. Таким чином, порушення ліпідного обміну при політравмі можна вважати предикторними щодо прогресування дисбалансу пероксидного окиснення ліпідів - антиоксидантного захисту - калікреїн-кінінової системи у травмованих тварин у різні терміни політравми. Це робить актуальним виявлення взаємозалежностей між оксидативним стресом, показниками ККС та параметрами системи АОЗ. Встановлено наявність обернених статистично значимих кореляційних зв'язків між показником МДА та активністю СОД і КАТ. Також було доведено наявність статистично значимих кореляційних зв'язків між показниками системи АОЗ (СОД, КАТ і ЦП) у ранні терміни після моделювання політравми. Отже, дисбаланс пероксидного окиснення ліпідів - антиоксидантного захисту - калікреїн-кінінової системи можна вважати предиктором у фрормуванні та поглибленні проявів тяжкої травми.

\section{СПИСОК ЛІТЕРАТУРИ}

1. Анализ госпитальной летальности и качества клинической диагностики у пострадавших с политравмой / Т. В. Левченко, С. А. Кравцов, А. Н. Корнев [и др.] // Политравма. - 2014. - № 3. - С. 24-40.

2. Калликреин-кининовая система как адаптационно-защитное звено организма / 3. Н. Третьякевич, А. М. Левчин, В. В. Анцупова, А. М. Федота // Современная медицина: актуальные вопросы : материаль XXII Междунар. заочн. науч.-практ. конф., 26 авг. 2013 г. - Новосибирск : СибАК, 2013. - С. 49-58.

3. Traumatic brainin jury and fracture / O. Ek, M. Muhr, A. L. Hulting, K. A. Jansson // Lancet. - 2013. 381 (9869). - P. 874.

4. Пат. на корисну модель 30028 Україна, МПК 2006 G 09 В 23/00. Спосіб моделювання політравми / Секела Т. Я., Гудима А. А. ; заявник і патентовласник Терноп. мед. ун-т. - № U 200710471 ; заявл. 21.09.07 ; опубл. 11.02.08, Бюл. № 3.

\section{REFERENCES}

1. Levchenko, T.V., Kravtsov, S.A., Kornev, A.N., Shatalin, A.V., Dzuban, G.G. (2014). Analiz gospitalnoy letalnosti i kachestva klinicheskoy diagnostiki u postradavshikh s politravmoy [Analysis of hospital mortality and quality of clinical diagnosis in victims with polytrauma]. Politravma - Polytrauma, (3), 24-40 [in Russian].

2. Tretyakevich, Z.N., Levchin, A.M., Antsupova, V.V., \& Fedota, A.M. (2013). Kallikrein-kininovaya sistema kak
5. Веремеенко К. Н. Протеолитические фрерменты и их ингибиторы. Новые области применения в клинике / К. Н. Веремеенко // Врач. дело. - 1994. - № 31. C. 8-13.

6. Гаврилов В. Б. Спектрофотометрическое определение гидроперекисей липидов в плазме крови / В. Б. Гаврилов, М. И. Мишкорудная // Лаб. дело. 1983. - № 3. - С. 33-35.

7. Чевари С. Роль супероксиддисмутазы в окислительных процессах клетки и метод определения ее в биологических материалах / С. Чевари, И. Чаба, Й. Секей // Лаб. дело. - 1985. - № 11. - С. 678-681.

8. Метод определения активности каталазы / М. А. Королюк, Л. И. Иванова, И. Г. Майорова, В. Е. Токарев // Лаб. дело. - 1988. - № 1. - С. 16-19.

9. Колб В. Г. Справочник по клинической химии / В. Г. Колб, В. С. Камышников. - Минск : Беларусь, 1982. $-311 \mathrm{c}$

adaptasionno-zashchitnoe zveno organizma [Kallikreinkinin system as an adaptation-protective link in the body]. "Sovremennaya meditsina: aktualnye voprosy": Materialy XXII mezhdunarodnoy zaochnoy nauchno-prakticheskoy konferentsii-Modern Medicine: Topical Issues: Materials of the XXII International Correspondence Scientificpractical Conference]. (pp. 49-58). Novosibirsk: SibAK [in Russian]. 
3. Ek, O., Muhr, M., Hulting, A.L., Jansson, K.A. (2013). Traumatic brain injury and fracture. Lancet, 381 (9869), 874.

4. Sekela, T.Ja., Gudyma, A.A. (2008). Ukrainian Patent U 2007 10471. Bul., (3).

5. Veremeenko, K.N. (1994). Proteoliticheskie fermenty i ikh ingibitory. Novye oblasti primeneniya $v$ klinike [Proteolytic enzymes and their inhibitors. New applications in the clinic]. Vrachebnoe delo-Medical Work, (31), 8-13 [in Russian].

6. Gavrilov, V.B., Mishkorudnaya, M.I. (1983). Spektrofotometricheskoe opredelenie gidroperekisey lipidov v plazme krovi [Spectrophotometric finding of lipids hydroperoxides in blood plasma]. Laboratornoe delo Laboratory Work, (3), 33-35 [in Russian].
7. Chevari, S., Chaba, I., Sokej, J. (1985). Rol superoksiddismutazy $v$ okislitelnykh protsessakh kletki i metod opredeleniya yeye $v$ biologicheskikh materialakh [The role of superoxide dismutase in the oxidative processes of the cell and the method of its finding in biological materials]. Laboratornoe delo - Laboratory Work, (11), 678-681 [in Russian].

8. Korolyuk, M.A., Ivanova, L.I., Mayorova, I.G., \& Tokarev, V.E. (1988). Metod opredeleniya aktivnosti katalazy [Method for finding of catalase activity]. Laboratornoe delo-Laboratory Work, (1), 16-19 [in Russian].

9. Kolb, V.G., \& Kamyshnikov, V.S. (1982). Spravochnik po klinicheskoy khimii [Handbook of Clinical Chemistry]. Minsk: Belarus [in Russian].

С. Р. Пидручная, Г. Н. Степанова ТЕРНОПОЛЬСКИЙ ГОСУДАРСТВЕННЫЙ МЕДИЦИНСКИЙ УНИВЕРСИТЕТ ИМЕНИ И. Я. ГОРБАЧЕВСКОГО

\section{ВЗАИМОЗАВИСИМОСТЬ ПРО- И АНТИОКСИДАНТНОГО СТАТУСА И КАЛЛИКРЕИН-КИНИНОВОЙ СИСТЕМЫ У ЖИВОТНЫХ РАЗНОГО ВОЗРАСТА ПРИ РАННЕЙ И ПОЗДНЕЙ ПОЛИТРАВМЕ}

\section{Резюме}

Вступление. Последние десятилетия характеризуются значительным ростом травматизма, особенно лиц молодого возраста, который имеет различные причины. Одним из патогенетических звеньев травматической болезни является нарушение прооксидантно-антиоксидантной и калликреин-кининовой систем. Данные об изменениях показателей перекисного окисления липидов - антиокидантной защиты - калликреин-кининовой системы у лиц разного возраста и в разные периоды травматической болезни разрознены и противоречивы.

Цель исследования - установить взаимозависимость между показателями про- и антиоксидантной систем и показателями общего и специфического протеолиза у крыс разного возраста при ранних и поздних проявлениях политравмы.

Методы исследования. Политравму моделировали под тиопентал-натриевым обезболиванием (60 мг/кг массы животного). В асептических условиях у животных из бедренной вены вызывали кровотечение (около 20 \% объема циркулирующей крови), 1 мл которой вводили в паранефральную клетчатку для воспроизведения эндогенной интоксикации. Далее с оперативного доступа щипцами Люэра ломали левую бедренную кость, рану на бедре зашивали. Исследование проводили на 1, 3, 24 час и на 14 сутки после моделирования политравмы. Активность супероксиддисмутазы в сыворотке крови определяли по методике Чевари, активность каталазы в гомогенате печени и плазме крови - по методике М. А. Королюка и соавт., содержание церулоплазмина в сыворотке крови - по методике В. Г. Колба, В. С. Камышникова, содержание ТБК-активных продуктов - по методике В. Б. Гаврилова, а показатели калликреин-кининовой системы - по методике К. Н. Веремеенко. Взаимосвязь двух признаков при наличии нормального распределения оценивали по результатам корреляционного анализа по Пирсону (r).

Результаты и обсуждение. Проанализировав взаимосвязь между показателями про- и антиоксидантной систем и показателями общего и специфического протеолиза на ранних сроках травматической болезни у животных 3-месячного возраста, мы установили наличие обратной статистически значимой корреляции между уровнем калликреина и активностью супероксиддисмутазы $(r=-0,69 ; p<0,05)$ на 1 час после моделирования политравмы. Об активации неспецифического протеолиза свидетельствовало наличие прямых статистически значимых корреляционных связей между протеолитической активностью и уровнем малонового диальдегида $(r=0,65 ; p<0,05)$ на 1 час и между протеолитической активностью и уровнем гидроперекисей липидов на 3 час травматической болезни ( $r=0,67 ; p<0,05)$. Уменьшение защитных механизмов системы антиоксидантной защиты подтверждала значимая обратная корреляция между протеолитической активностью и уровнем каталазы в крови животных 3-месячного возраста на ранних сроках политравмы (r=-0,67; $p<0,05)$. В половозрелых 6-месячных крыс на 1 час после моделирования политравмы зафиксированы обратные статистически значимые корреляционные связи между уровнями калликреина, каталазы в крови и церулоплазмина в сыворотке крови (r=0,89 и r=0,72 coomветственно; $p<0,05)$. На 3 час эксперимента установлено наличие обратных корреляционных связей между уровнем прекалликреина и активностью каталазы в печени $(r=-0,80 ; p<0,05)$, что доказывает уменьшение защитных ресурсов системы антиоксидантной защиты на фроне активации калликреин-кининовой системы. 
Вывод. Обнаруженные корреляционные связи подтверждают то, что возрастание интенсификации процессов перекисного окисления липидов, активация общего и специфического протеолиза калликреинкининовой системы и уменьшение адаптационных ресурсов системы антиоксидантной защиты ведут к углублению липидного дисбаланса у животных разных возрастных групп с политравмой и, наоборот, углубление нарушений в липидном статусе является причиной повышения дисбаланса в системе перекисного окисления липидов - антиоксидантной защиты - калликреин-кининовой системы.

КЛЮЧЕВЫЕ СЛОВА: политравма; крысы; возраст; перекисное окисление липидов; антиоксиданты; калликреин-кининовая система.

S. R. Pidruchna, H. M. Stepanova

I. HORBACHEVSKY TERNOPIL STATE MEDICAL UNIVERSITY

\section{INTERDEPENDENCE OF THE PRO- AND ANTIOXIDANT STATUS AND KALLIKREIN-KININ SYSTEM IN ANIMALS OF DIFFERENT AGE IN CONDITIONS OF EARLY AND LATE POLYTRAUMA}

Summary

Introduction. The last decades are characterized by significant growth of injuries, especially in young people, which have a variety of causes. One of the pathogenetic links of traumatic disease is a violation of prooxidantantioxidant and kallikrein-kinin systems. Data on changes in the indicators of the system of lipid peroxidation antioxidant defense - kallikrein-kinin system are disparate and contradictory in people of all ages and at different periods of traumatic disease.

The aim of the study - to establish interdependence between pro- and antioxidant system and general and specific proteolysis parameters in rats of different ages in early and late display of polytrauma.

Research Methods. Simulation of polytrauma was performed under the thiopental sodium anesthetizing (60 mg per kilogram of weight). In aseptic conditions, the animals were caused bleeding from the femoral vein (about $20 \%$ of the volume of circulating blood), $1 \mathrm{ml}$ of which was injected into a paranephrine cellulose to reproduce endogenous intoxication. Then from the operative access by the forceps of Luer, the left astragalus was broken, a wound on the thigh was sewn. The research was conducted after 1, 3, 24 hours and 14 days after the polytraumatic simulation. The activity of superoxide dismutase in blood serum was determined by Chiavari's method. The activity of catalase in the liver homogenate and blood plasma was determined by the method of M. A. Koroliuk and co-authors. The content of ceruloplasmin in blood serum was determined according to the method of V. H. Kolba, V. S. Kamyshnikov. The content of TBA-active products was determined according to the method of $B$. V. Havrylov, and indicators of kallikrein-kinin system - by K. M. Veremieienko. The analysis of the interdependency between the two features in the presence of a normal distribution was estimated following the results of the Pearson's correlation analysis ( $r$ ).

Results and Discussion. Having analyzed the interdependency between the pro- and antioxidant system and the indicators of the general and specific proteolysis in the early stages of traumatic disease in animals 3 months of age, we established the presence of a statistically significant inverse correlation between the level of kallikrein and the activity of superoxide dismutase $(r=-0.69 ; p<0.05)$ for one hour after the polytraumatic simulation. The activation of nonspecific proteolysis was confirmed by the presence of direct statistically significant correlation bonds between the level of proteolytic activity and the level of malondialdehyde $(r=0.65 ; p<0.05)$ for 1 hour and between proteolytic activity and the level of lipids hydroperoxides for 3 hours of traumatic disease $(r=0.67 ; p<0.05)$. The decrease in the protective mechanisms of the antioxidant defense system confirmed a significant inverse correlation between proteolytic activity and the catalase of blood in the early stages of polytrauma $(r=-0.67 ; p<0.05)$ in animals 3 months of age. In the reproductive rats 6 months of age for 1 hour after polytraumatic simulation, fixed inverse statistically significant correlation relations between the level of kallikrein, blood catalase and ceruloplasmin of blood serum ( $r=0.89$ and $r=0.72$, respectively; $p<0.05$ ). For $3^{r d}$ hour of the experiment, the existence of inverse correlation relationships between the level of precalicine and the activity of the liver catalase $(r=-0.80 ; p<0.05)$ was established, which proves the decrease of protective resources of antioxidant defense system with the activation of kallikrein-kinin system.

Conclusion. Detected dependencies confirm that increase of the intensification of lipid peroxidation processes, the activation of general and specific kallikrein-kinin system proteolysis, and the reduction of adaptive resources of antioxidant defense system leads to an increase in lipid disequilibrium in animals of different age groups with polytrauma and vice versa, the increase of lipid status disorders leads to an increase in disequilibrium in the system of lipid peroxidation - antioxidant defense - kallikrein-kinin system.

KEY WORDS: polytrauma; rats; lipid peroxidation; antioxidants; kallikrein-kinin system.

Отримано 15.11.17

Адреса для листування: С. Р. Підручна, Тернопільський державний медичний університет імені І. Я. Горбачевського, майдан Волі, 1, Тернопіль, 46001, Україна, e-mail: pidruchna@tdmu.edu.ua. 